\title{
Optimal photoperiod for indoor cultivation of leafy vegetables
} and herbs

\author{
G. Pennisi ${ }^{1}$, F. Orsini ${ }^{1}$, M. Landolfo ${ }^{1}$, A. Pistillo ${ }^{1}$, A. Crepaldi ${ }^{2}$, S. Nicola ${ }^{3}$, J.A. Fernández ${ }^{4}$, L.F.M. Marcelis ${ }^{5}$ \\ and G. Gianquinto ${ }^{1}$ \\ ${ }^{1}$ DISTAL, Agricultural and Food Sciences Department, Alma Mater Studiorum - University of Bologna, Bologna, Italy \\ 2 Flytech s.r.l., Belluno, Italy \\ ${ }^{3}$ DISAFA-VEGMAP, Department of Agricultural, Forest and Food Sciences, University of Turin, Turin, Italy \\ ${ }^{4}$ Departamento de Ingeniería Agronómica, Universidad Politécnica de Cartagena, Cartagena, Spain \\ ${ }^{5}$ Wageningen UR Horticulture and Product Physiology, Wageningen, The Netherlands
}

\section{Summary}

In Vertical Farms with Artificial Lighting (VFALs), optimal light management is a crucial determinant of both economic and environmental viability. Applications of LED technologies to plant cultivation are still recent, and research has to date mainly targeted the definition of optimal spectral and light intensity features. On the other hand, despite the relevant implications on production costs, literature on optimal photoperiod management is to date limited. Indeed, the number of hours per day correlates with the total light supplied to the crop - expressed as Daily Light Integral (DLI) - and the associated energetic costs. The present study aims at defining how photoperiods of $16 \mathrm{~h} \mathrm{~d}^{-1}$ (DLI= $14.4 \mathrm{~mol} \mathrm{~m}^{-2} \mathrm{~d}^{-1}$ ), $20 \mathrm{~h} \mathrm{~d}^{-1}$ (DLI= $18 \mathrm{~mol}$ $\mathrm{m}^{-2} \mathrm{~d}^{-1}$ ) and $24 \mathrm{~h} \mathrm{~d}^{-1}$ (DLI= $21.6 \mathrm{~mol} \mathrm{~m}^{-2} \mathrm{~d}^{-1}$ ) of light affect growth performances and resource use efficiency in leafy vegetables and herbs, represented by lettuce (Lactuca sativa L.), basil (Ocimum basilicum L.), rocket (Eruca sativa Mill.), and chicory (Cichorium intybus L.). Plants were cultivated indoor under a red (R) and blue (B) LED light $(\mathrm{RB}=3$, photosynthetic photon flux density $\left(\right.$ PPFD) $=250 \mu \mathrm{mol} \mathrm{m}{ }^{-2} \mathrm{~s}^{-1}$ ). Photoperiod variations' effects differed according to the considered plant species. In lettuce and chicory, the adoption of a DLI of $14.4 \mathrm{~mol} \mathrm{~m}^{-2} \mathrm{~d}^{-1}$ at $16 \mathrm{~h} \mathrm{~d}^{-1}$ photoperiod resulted in a greater plants fresh biomass and leaf area, which also contributed to generally obtain higher energy use efficiency (fresh biomass per unit of electricity input), light use efficiency (dry biomass per unit of light input) and, in chicory, also water use efficiency (fresh biomass per liter of water consumed). Contrarily, although photoperiod variations did not affect basil and rocket growth parameters (e.g., fresh biomass and leaf area) and the plant capacity to transform resources (e.g., water use efficiency and light use efficiency), energy use efficiency in basil also presented a downward trend in response to growing DLI. Accordingly, the adoption of a DLI of $14.4 \mathrm{~mol} \mathrm{~m}^{-2} \mathrm{~d}^{-1}$ at $16 \mathrm{~h} \mathrm{~d}^{-1}$ photoperiod resulted to be the optimal option among the ones tested in the presented research.

Keywords

Daily Light Integral (DLI), Plant Factory with Artificial Lighting (PFAL), vertical farm, Water Use Efficiency (WUE), Light Use Efficiency (LUE), Energy Use Efficiency (EUE)

\section{Significance of this study}

What is already known on this subject?

- LED light sustains plant growth in vertical farms. Research on plant growth and resources use in response to photoperiod management is limited.

What are the new findings?

- Fresh biomass and energy use efficiency of lettuce, chicory, basil and rocket were optimal when DLI is $14 \mathrm{~mol} \mathrm{~m}^{-2} \mathrm{~d}^{-1}$ at a photoperiod of $16 \mathrm{~h} \mathrm{~d}^{-1}$.

What is the expected impact on horticulture?

- Using a photoperiod of up to $16 \mathrm{~h} \mathrm{~d}^{-1}$ (DLI = $14 \mathrm{~mol}$ $\left.\mathrm{m}^{-2} \mathrm{~d}^{-1}\right)$ in chicory and lettuce cultivation may improve yield and sustainability.

\section{Introduction}

The rapid evolution in plant LED lighting technologies experienced in the last decade has resulted in revolutionary changes in the greenhouse and controlled-environment agricultural industry sector (Gómez and Izzo, 2018). From the first researches on potential applications in outer space (Massa et al., 2008), current application of LED lighting ranges from the progressive substitution of incandescent lights used in the photoperiod management for flowering species (Craig and Runkle, 2013), up to the replacement of both fluorescent lamps in growth rooms (Yeh and Chung, 2009) and high pressure sodium (HPS) lamps for supplemental lighting in greenhouses (Olle and Viršile, 2013). Indeed, in response to multiple stressors affecting the viability of global food systems in the coming decades (which include, among other, the effects of population growth and urbanization, climate change and resource scarcity), the most promising application of LED lighting in horticulture is likely in the socalled vertical farms (Al-Chalabi, 2015). In Vertical Farms with Artificial Lighting (VFALs), where radiation for photosynthesis is solely supplied through lamps, the efficiency of light assimilation is crucial for plant growth performance, as well as for the environmental and economic sustainability of the production system (Kozai, 2020). To date, however, a major share of research on VFALs has only targeted cultivation of a limited range of crops (Kozai, 2016a). First studies addressed LED applications on cereals, including wheat (Goins et al., 1997; Dougher and Bugbee, 2001; Morrow, 2008). It rapidly emerged, however, that cultivation of staple 
crops would hardly meet the energetic and economic costs associated with indoor cultivation (Banerjee and Adenaeuer, 2014). Alternatively, cultivation of fresh fruits and vegetables could benefit from the higher value of the products (which may also benefit from the consumer preference toward locally produced and fresher food) as well as the avoided or reduced burdens that are currently associated with post-harvest transportation and refrigeration (Al Chalabi, 2015). Accordingly, in recent years, leafy vegetables and herbs have been the major research target crops for cultivation within VFALs. As compared with fruit vegetables, they present a number of advantages, which include their small volume, the elevated harvest index (which maximises the amount of dry biomass produced per unit of light received), and the limited requirements for light intensity (Dou et al., 2018; Pennisi et al., 2020). Among these crop categories, recent studies have largely targeted applications in lettuce (Lactuca sativa L.) and sweet basil (Ocimum basilicum L.), addressing implications on metabolic and aromatic profiles, as well as the definition of their resource use efficiency (Dou et al., 2018; Pennisi et al., 2019a, b; Viršilè et al., 2019; Yan et al., 2019). Furthermore, the potential for cultivation within VFALs was also recently explored in other leafy vegetables, including rocket (Eruca sativa Mill.) and chicory (Cichorium intybus L.), whose production for the ready-to-eat sector may sustain VFALs economic viability (Taulavuori et al., 2018; Pennisi et al., 2019c; Kozai and Niu, 2020). Moreover, while research on LED light management in VFALs has mostly targeted the definition of optimal spectral composition (Carvalho et al., 2016; Clavijo-Herrera et al., 2018; Pennisi et al., 2019a, b) and recommended Photosynthetic Photon Flux Density (PPFD) (Dou et al., 2018; Viršilè et al., 2019; Yan et al., 2019; Pennisi et al., 2020), studies targeting the optimal photoperiod management under LED lighting are, to date, only limited, notwithstanding its crucial role in plants growth and development. Accordingly, photoperiod may influence several molecular mechanisms related to the leaf detection of light signal, circadian rhythm operation, transduction of light signal, which may alter growth, flowering time, abiotic and biotic stress responses, and plants metabolism (Jackson, 2009; Greenham and McClung, 2015).

Most of the available research on indoor leafy vegetables cultivation adopted long days photoperiod (e.g., 16 hours of light per day) (Shimizu et al., 2011), building on the evidence that shorter days would result in lower plant growth and biomass production (Lee and Kim, 2013). Furthermore, some crops (including lettuce) have shown to feasibly stand also continuous light conditions (Ikeda et al., 1987; VelezRamirez et al., 2011). These results were also confirmed in a more recent study, where fluorescent lamps supplied either 12,18 or $24 \mathrm{~h} \mathrm{~d}^{-1}$ of light, achieving the larger growth when lettuce plants were continuously irradiated (Park et al., 2012). In another study (Kang et al., 2013), it was shown that lettuce would present higher shoot fresh weight when grown under two cycles of 9:3 (light:dark) hours per day, as compared with a single cycle of $18: 6$, which on the other hand resulted in higher leaf dry weight, suggesting that changes in the plant circadian rhythms would also alter leaf morphological parameters and assimilates allocation. However, in VFALs, where solar radiation is not used, the length of the day is directly related to the energetic costs. Therefore, the need of identifying the optimal photoperiod must build on the mutual relationship between yield and energy costs in response to day length increases.

Building on this ground, the present research aims at identifying the morphological and physiological responses of four vegetable and herb crops (lettuce, basil, rocket and chicory) to variations in the supply of Daily Light Integrals (DLIs) through photoperiod management. The study also explores on how photoperiod alters resource use efficiency, particularly with reference to water, energy and light.

\section{Materials and methods}

\section{Plant material and growth conditions}

Plants were grown in three separate compartments $\left(2 \mathrm{~m}^{2}\right.$ surface and $3.6 \mathrm{~m}^{3}$ volume) in a climate-controlled growth chamber $\left(24 \pm 2^{\circ} \mathrm{C}\right.$ air temperature, $55-70 \%$ relative humidity and $450 \mu \mathrm{mol} \mathrm{mol}^{-1} \mathrm{CO}_{2}$ ) at the University of Bologna (Italy). Each compartment was insulated by using light opaque white walls, and equipped with fans constantly replacing internal air (hourly exchange rate of $35 \mathrm{v}: \mathrm{v}$ ). Three independent experiments were conducted on four plant species, namely lettuce (Lactuca sativa L. 'Rebelina', belonging to the typology Gentilina), basil (Ocimum basilicum L. 'Superbo', belonging to the typology Genovese), rocket (Eruca sativa Mill., 'Coltivata') and chicory (Cichorium intybus L. 'Bionda a foglie larghe'). In all three experiments and four crop species, a planting density of 100 plants $\mathrm{m}^{-2}$ and a crop cycle length of 21 days after transplant (DAT) to harvest, were adopted. Seeds were germinated in polystyrene containers filled with a mixture of peat $(70 \%)$ and vermiculite $(30 \%)$, under fluorescent lamps (using a PPFD of $215 \mu \mathrm{mol} \mathrm{m}{ }^{-2} \mathrm{~s}^{-1}$ and a photoperiod of $16 \mathrm{~h} \mathrm{~d}^{-1}$ of light). When plants reached a two true leaf stage (14 days after sowing for lettuce, rocket and chicory, and 21 days after sowing for basil), roots were washed, and plantlets were transplanted into a hydroponic deep water culture system. Each growing unit was composed by a plastic tray ( $5 \mathrm{~L}$ of volume), covered by a polypropylene panel hosting 6 plants and filled with nutrient solution $(\mathrm{EC}=1.6, \mathrm{pH}=6.5)$ with the following composition: $\mathrm{N}-\mathrm{NO}_{3}$ : $14 \mathrm{mM}$; $-\mathrm{NH}_{4}^{+}$: $4.4 \mathrm{mM}$; P: $1.0 \mathrm{mM}$; K: $5.0 \mathrm{mM}$; $: 2.0 \mathrm{mM}$; Ca: $1.2 \mathrm{mM}$; Mg: $5.2 \mathrm{mM}$; Fe: $17.9 \mu \mathrm{M}$; Cu: $2.0 \mu \mathrm{M}$; Zn: $3.8 \mu \mathrm{M}$; B: $11.6 \mu \mathrm{M}$; Mn: $18.2 \mu \mathrm{M}$; Mo: $0.5 \mu \mathrm{M}$. The nutrient solution was constantly aerated through air pumps (Airline 3, Haquoss, Turin, Italy, air exchange rate of $0.25 \mathrm{~L} \mathrm{~min}^{-1}$ pot ${ }^{-1}$ ). At $14 \mathrm{DAT}$, trays were replenished with $2 \mathrm{~L}$ of fresh nutrient solution. In each experiment, each compartment hosted three plastic trays per species, for a total of 12 trays.

\section{Light treatments}

After transplanting, plants were grown under dimmable LED lamps (Flytech s.r.l., Belluno, Italy) featuring hyper red (peak at $669 \mathrm{~nm}$ ) and blue (peak at $465 \mathrm{~nm}$ ) emitting diodes. The lamps were set to supply a spectral composition with a red:blue ratio of $3(\mathrm{RB}=3)$, such ratio being calculated by the relative spectral areas within the red (600-700 nm) and the blue ( $400-500 \mathrm{~nm}$ ) regions (Singh et al., 2015), and a photosynthetic photon flux density of $250 \mu \mathrm{mol} \mathrm{m}{ }^{-2} \mathrm{~s}^{-1}$. Light electricity power consumption was $164 \mathrm{~W} \mathrm{~m}^{-2}$. The spectral distribution was measured using an illuminance spectrophotometer (CL-500A, Konica Minolta, Chiyoda, Tokyo, Japan). A PAR Photon Flux Sensor (with equal sensitivity to red and blue radiation), model QSO (Apogee Instruments, Logan, UT, USA) connected with a ProCheck handheld reader (Decagon Devices Inc., Pullman, WA, USA) was used to set Photosyn-

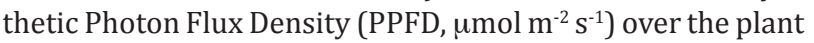
canopy. Electric power consumption (expressed in $\mathrm{W}=\mathrm{J} \mathrm{s}^{-1}$ ) was measured using a multimeter (Fluke 189, Fluke Corporation, Everett, WA, USA). In order to define the lamp's ef- 
ficacy of electricity-to-light conversion, the Photosynthetic Photon Efficacy (PPE) (expressed in $\mu \mathrm{mol}^{-1}$ ) was calculated as the ratio between PPFD and electric power consumption, resulting to be $1.52 \mu \mathrm{mol} \mathrm{J}^{-1}$.

Three LED light treatments were applied, one per each compartment, characterised by different DLIs (namely 14.4 , 18 and $21.6 \mathrm{~mol} \mathrm{~m}^{-2} \mathrm{~d}^{-1}$ ) obtained by changing the photoperiod (respectively 16, 20 and $24 \mathrm{~h} \mathrm{~d}^{-1}$ of light).

\section{Growth analysis and resource use efficiency}

At harvest (21 DAT), fresh biomass, also referred to as fresh weight (FW), of shoot and root was measured in all experiments and dry biomass, also referred to as dry weight (DW), was quantified after drying samples at $60^{\circ} \mathrm{C}$ for 72 hours. Root-shoot ratio (RS) was determined as the ratio of root dry biomass to shoot dry biomass. Leaf number was counted, and leaf area was determined using a leaf area meter (LI-3100C, LI-COR, Lincoln, Nebraska, USA). Specific Leaf Area (SLA) was calculated as the ratio between plant leaf area and leaf dry biomass. For basil plants, also plant height was measured.

Water use was quantified for each tray during each experiment and Water Use Efficiency (WUE) was determined as the ratio between fresh weight and the volume of water used, and expressed as g FW L-1 $\mathrm{H}_{2} \mathrm{O}$. Lighting energy use efficiency (EUE) was determined according to the crop cycle length and the final fresh weight of the shoot, related to the lamps' cumulated electricity absorption (measured using a multimeter model Fluke 189, Fluke Corporation, Everett,

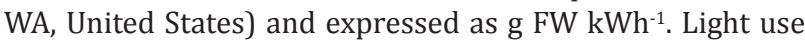

efficiency (LUE) was calculated as the ratio of shoot dry weight production per unit surface of cultivation ( $\mathrm{g} \mathrm{DW} \mathrm{m}^{-2}$ ) and the light integral (obtained by multiplying DLI values per the number of days between transplanting and harvest, expressed as $\mathrm{mol} \mathrm{m}^{-2}$ ), and expressed as $\mathrm{g} \mathrm{DW} \mathrm{mol}^{-1}$.

\section{Stomatal conductance}

Measurements of stomatal conductance $\left(\mathrm{mmol} \mathrm{m}^{-2} \mathrm{~s}^{-1}\right)$ were performed on the third fully expanded leaf using a leaf porometer $(\Delta \mathrm{P} 4$, Delta-T Devices, Cambridge, UK) at 14 DAT in each experiment.

\section{Leaf chlorophyll content}

Concentration of chlorophyll in leaves was estimated during each experiment at 14 DAT through a leaf chlorophyll meter (SPAD 502, Spectrum Technologies Inc., Aurora, IL, USA) on the third fully expanded leaf.

\section{Statistical analysis}

Measurements were conducted on 18 plants per light treatment per species per experiment, which were surrounded by border plants. Data were analysed by one-way ANOVA considering experiments as replicates and the means were compared by Tukey's HSD test, at 5\% significance level. Before the analysis, all data were checked for normality and homogeneity of the variance. The linear response to levels of photoperiod was assessed by the orthogonal polynomial contrast. Significance level was set at $P<0.05$. For all statistical analyses, R (v. 3.3.2) software was used.
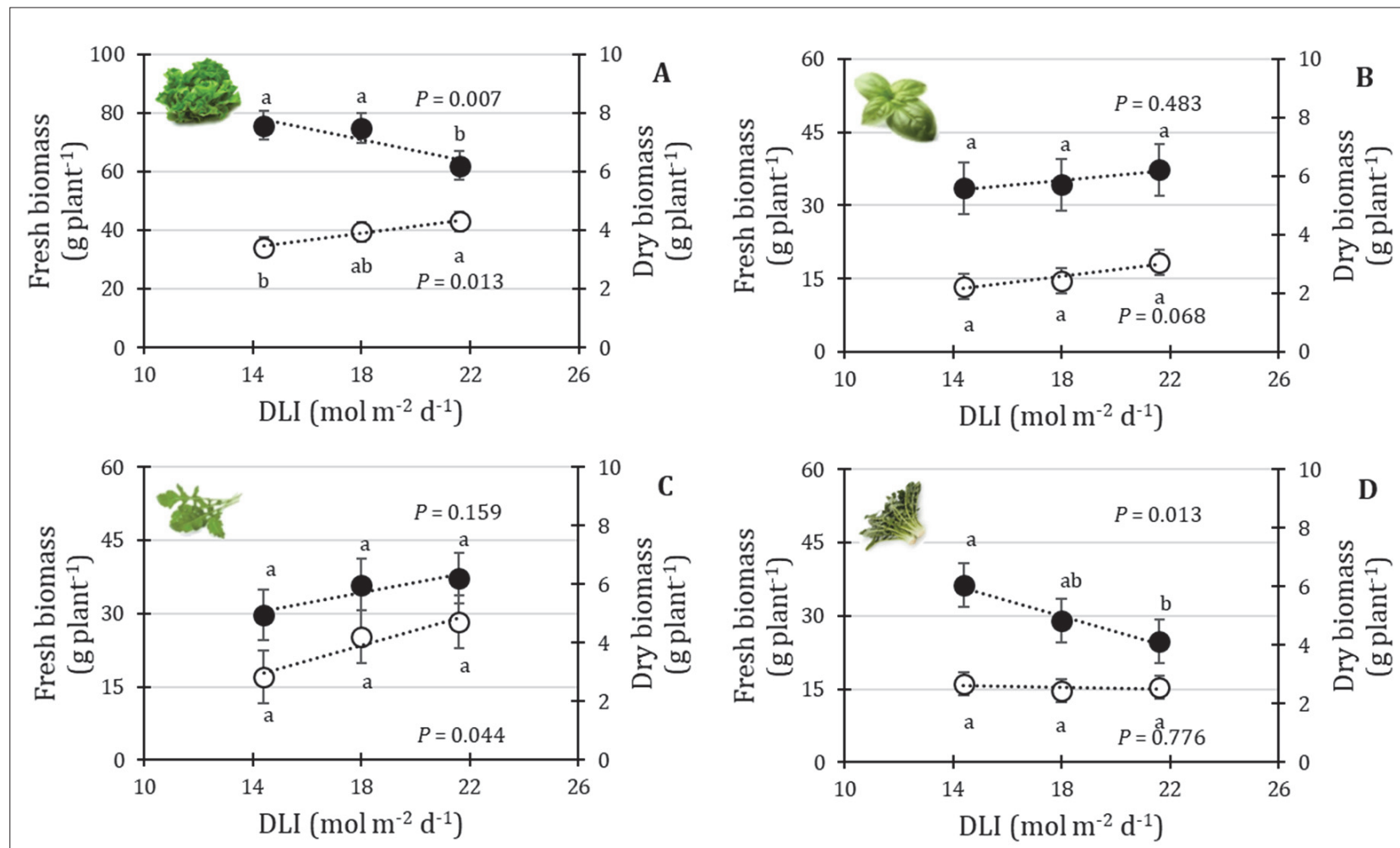

FiguRE 1. Fresh biomass (closed symbols) and dry biomass (open symbols) of (A) lettuce, (B) basil, (C) rocket and (D) chicory plants grown under different DLI obtained by changing photoperiod, respectively at $14.4\left(16 \mathrm{~h} \mathrm{~d}^{-1}\right), 18\left(20 \mathrm{~h} \mathrm{~d}^{-1}\right)$ and $21.6 \mathrm{~mol}$ $\mathrm{m}^{-2} \mathrm{~d}^{-1}\left(24 \mathrm{~h} \mathrm{~d}^{-1}\right)$. Each value is the mean of three experiments, each with 18 replicate plants. Vertical bars represent SE. Different letters indicate statistically significant differences compared by Tukey's HSD test, at $5 \%$ significance level. P values represent the significance of the linear component. 


\section{Results}

\section{Plant growth parameters and leaf gas exchanges}

Fresh biomass production of lettuce plants linearly decreased $(P=0.007)$ as a result of DLI increase, with plants grown under the highest DLI $\left(21.6 \mathrm{~mol} \mathrm{~m}^{-2} \mathrm{~d}^{-1}\right)$ presenting the lowest fresh biomass $(-18 \%)$ as compared to plants grown under a DLI of 14.4 or $18 \mathrm{~mol} \mathrm{~m}^{-2} \mathrm{~d}^{-1}$ (Figure 1A). Contrarily, a linear $(P=0.013)$ significant increase in lettuce dry biomass $(+26 \%)$ was observed when DLI was increased from 14.4 to $21.6 \mathrm{~mol} \mathrm{~m}^{-2} \mathrm{~d}^{-1}$ (Figure 1A). In basil (Figure 1B) and rocket (Figure 1C) plants, lighting regimes did not statistically affect fresh biomass. When considering dry biomass, a significant $(P=0.044)$ linear increase was associated with DLI increase in rocket plants (Figure 1C), while dry biomass did not respond to variation of DLI in basil (Figure 1B) and chicory (Figure 1D) plants. As in the case of lettuce plants, fresh biomass of chicory plants linearly decreased $(P=0.013)$ in response to DLI increase, with higher $(+47 \%)$ fresh biomass detected in plants grown under 14.4 as compared with those supplied with $21.6 \mathrm{~mol} \mathrm{~m}^{-2} \mathrm{~d}^{-1}$ (Figure 1D).

Dry matter content linearly increased with the increase of DLI, resulting the highest in lettuce (Figure 2A), basil (Figure 2B) and chicory (Figure 2D) plants grown at $21.6 \mathrm{~mol} \mathrm{~m}^{-2} \mathrm{~d}^{-1}$. In rocket plants, dry matter was not significantly affected by variation in DLI (Figure 2C). RS ratio was not affected by lighting treatments in the four studied species (data not shown). Leaf number was not affected by DLI in basil, chicory and rocket, whereas a linear decrease $(P=0.025)$ in response to growing DLI was observed only in lettuce (data not shown).

Leaf area of lettuce and chicory and specific leaf area of the four studied species linearly decreased with the increase of DLI (Figure 3). Accordingly, in lettuce and chicory, higher leaf area $(+32 \%$ and $+81 \%$, respectively) and specific leaf area $(+64 \%$ and $70 \%$, respectively) were observed in plants grown under 14.4 as compared with $21.6 \mathrm{~mol} \mathrm{~m}^{-2} \mathrm{~d}^{-1}$ (Figure $3 \mathrm{~A}, \mathrm{D})$. In basil and rocket, although no changes occurred in leaf area, specific leaf area was higher $(+30 \%$ and $+45 \%$, respectively) in plants grown under 14.4 as compared with $21.6 \mathrm{~mol} \mathrm{~m}^{-2} \mathrm{~d}^{-1}$ (Figure 3B, C).

In basil, rocket and chicory, chlorophyll content linearly increased $(P=0.012, P=0.038$ and $P=0.012$, respectively) in response to growing DLI (Table 1 ). Contrarily, no responses to DLI variations were observed in chlorophyll content of lettuce plants (Table 1). Moreover, when DLI was augmented, leaf stomatal conductance linearly decreased in lettuce $(P=0.011)$ and basil $(P=0.005)$ plants, while it did not vary in rocket and chicory (Table 1$)$.

\section{Input use efficiency}

From a resources use perspective, water use per plant was not significantly affected by light regimes in lettuce, basil, rocket and chicory (data not shown), with mean values of $1.03,0.97,0.81$ and 0.86 L plant $^{-1}$, respectively. Accordingly, with regard to the capacity of plants to transform resources, water use efficiency (WUE) did not vary among lighting treatments in lettuce, basil and rocket plants (mean value of 64.2, 36.0 and $31.4 \mathrm{~g} \mathrm{FW} \mathrm{L}^{-1} \mathrm{H}_{2} \mathrm{O}$, for these three species respectively) (Figure 4A). Contrarily, in chicory WUE linearly $(P=0.015)$ decreased with the increase of DLI, being WUE $33 \%$ higher in plants grown under $14.4 \mathrm{~mol} \mathrm{~m}^{-2} \mathrm{~d}^{-1}$ as compared to plants grown under $21.6 \mathrm{~mol} \mathrm{~m}^{-2} \mathrm{~d}^{-1}$ (Figure 4A).

Changes in DLI resulted in variations in energy use along the crop cycle, which respectively resulted in daily electricity requirements of $2.6 \mathrm{kWh} \mathrm{m}^{-2} \mathrm{~d}^{-1}$ (under $14.4 \mathrm{~mol} \mathrm{~m}^{-2} \mathrm{~d}^{-1}$ ), $3.3 \mathrm{kWh} \mathrm{m}^{-2} \mathrm{~d}^{-1}$ (under $18 \mathrm{~mol} \mathrm{~m}^{-2} \mathrm{~d}^{-1}$ ) and $3.9 \mathrm{kWh} \mathrm{m}^{-2} \mathrm{~d}^{-1}$ (under $21.6 \mathrm{~mol} \mathrm{~m}^{-2} \mathrm{~d}^{-1}$ ). Accordingly, in lettuce and chicory crops, energy use efficiency (EUE; fresh biomass per electricity use) was significantly reduced (respectively by 83 and $120 \%$ ) when DLI of $21.6 \mathrm{~mol} \mathrm{~m}^{-2} \mathrm{~d}^{-1}$ was used as compared with $14.4 \mathrm{~mol} \mathrm{~m}^{-2} \mathrm{~d}^{-1}$ (Figure 4B). A linear downward trend $(P=0.011)$ in response to rise in DLI was also evidenced in basil plants (Figure 4B). Contrarily, energy use efficiency in rocket plants did not vary with variation of DLI (mean value $50 \mathrm{~g} \mathrm{FW} \mathrm{kWh}^{-1}$ ) (Figure 4B).

In chicory, light use efficiency (LUE; dry biomass per light integral) resulted the highest in plants grown under $14.4 \mathrm{~mol}$ $\mathrm{m}^{-2} \mathrm{~d}^{-1}$ with an increase of $57 \%$ as compared to plants grown under higher DLI (Figure 4C). Similarly, a linear downward trend $(P=0.028)$ in response to increasing DLI was observed in lettuce (Figure 4C). On the other hand, in basil and rocket plants no changes in LUE occurred (Figure 4C).

\section{Discussion}

\section{Crop species respond differently to DLI variations}

It is a well-documented phenomenon that variations of DLI influence vegetative growth of plants (Poorter et al., 2019). To date, several researches addressed the effect of variation of DLI through changes in light intensity in several indoor-grown crops, including lettuce (Nájera and Urrestarazu, 2019; Meng and Runkle, 2019; Yan et al., 2019), kale and spinach (Baumbauer et al., 2019), basil (Beaman et al., 2009; Dou et al., 2018; Meng and Runkle, 2019), rocket, endive, radish, and beetroot (Nájera and Urrestarazu, 2019). On the other hand, the consequences of changing DLI through modifications of photoperiod in indoor cultivation

TABLE 1. Effect of DLI (obtained by changing photoperiod from 16 to $24 \mathrm{~h} \mathrm{~d}^{-1}$ light) on leaf chlorophyll content (estimated by SPAD-value) and stomatal conductance (measured by leaf porometer) of lettuce, basil, rocket and chicory plants after three weeks of growth at a light intensity of $250 \mu \mathrm{mol} \mathrm{m}{ }^{-2} \mathrm{~s}^{-1}$.

\begin{tabular}{|c|c|c|c|c|c|c|c|c|c|c|c|c|}
\hline \multirow[t]{2}{*}{$\mathrm{DLI}\left(\mathrm{mol} \mathrm{m} \mathrm{m}^{-2} \mathrm{~d}^{-1}\right)$} & \multicolumn{6}{|c|}{$\begin{array}{l}\text { Chlorophyll content } \\
\text { (SPAD-value) }\end{array}$} & \multicolumn{6}{|c|}{$\begin{array}{l}\text { Stomatal conductance } \\
\qquad\left(\mathrm{mmol} \mathrm{m} \mathrm{m}^{-2} \mathrm{~s}^{-1}\right)\end{array}$} \\
\hline & Lettuce & Basi & & Rocket & Chico & & Lettu & & Bas & & Rocket & Chicory \\
\hline $14.4\left(16 \mathrm{~h} \mathrm{~d}^{-1}\right)$ & 34.33 & 44.06 & $b$ & 64.74 & 39.95 & $\mathrm{~b}$ & 236.4 & $a$ & 190.0 & $a$ & 292.0 & 224.8 \\
\hline $18\left(20 \mathrm{~h} \mathrm{~d}^{-1}\right)$ & 35.17 & 46.90 & $a b$ & 65.75 & 42.25 & $a b$ & 230.9 & b & 178.5 & $a b$ & 289.8 & 218.6 \\
\hline $21.6\left(24 \mathrm{~h} \mathrm{~d}^{-1}\right)$ & 35.22 & 48.89 & a & 70.55 & 44.11 & a & 198.8 & c & 164.2 & $b$ & 280.2 & 222.2 \\
\hline$P$ value & 0.562 & 0.012 & & 0.038 & 0.012 & & 0.011 & & 0.005 & & 0.443 & 0.847 \\
\hline
\end{tabular}

Each value is the mean of three experiments, each with 18 replicate plants.

Different letters indicate significant differences compared by Tukey's HSD test, at $5 \%$ significance level.

$P$ values represent the significance of the linear component. 

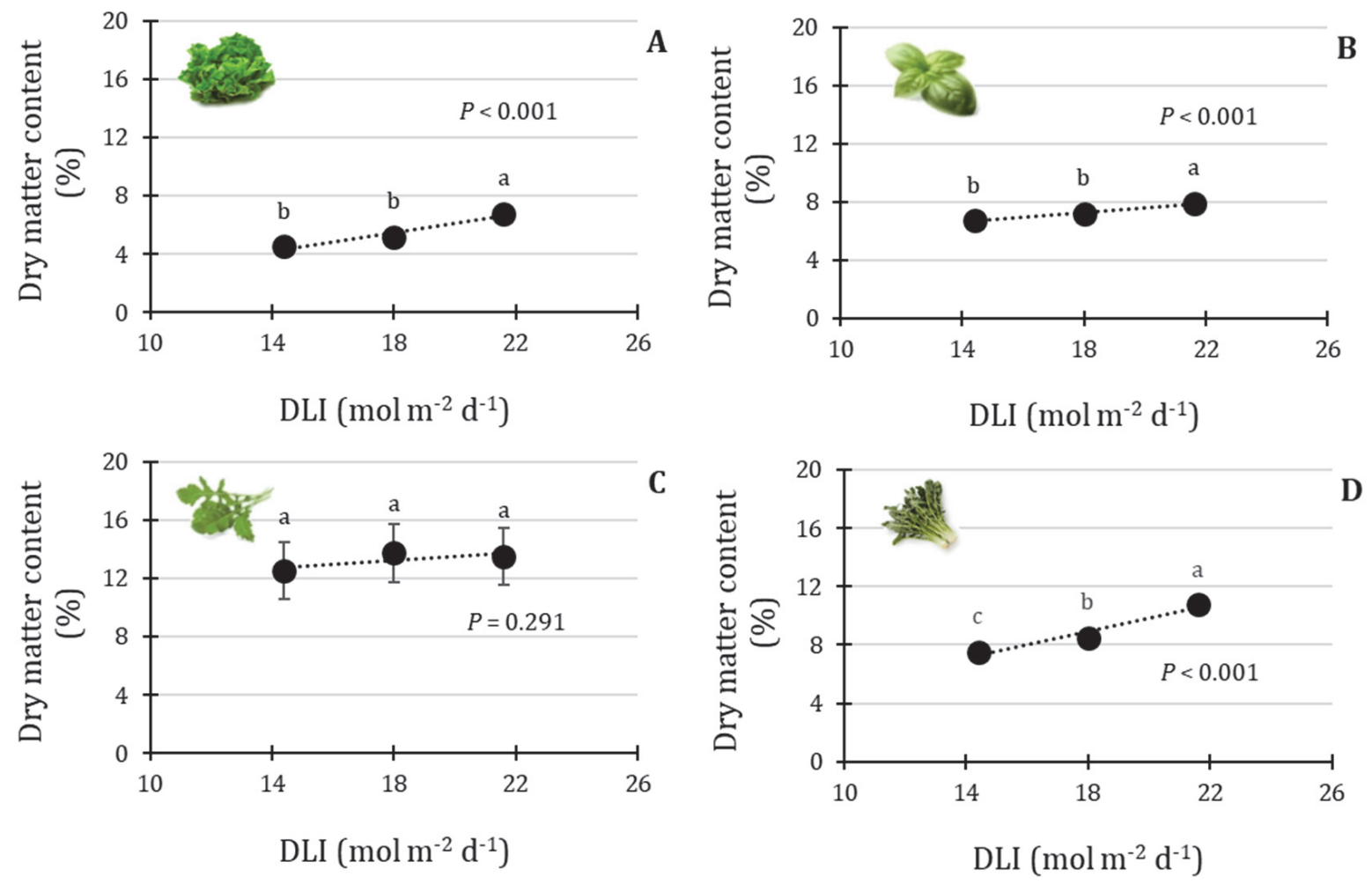

FigurE 2. Dry matter content of (A) lettuce, (B) basil, (C) rocket and (D) chicory plants grown under different DLI obtained by changing photoperiod, respectively at $14.4\left(16 \mathrm{~h} \mathrm{~d}^{-1}\right), 18\left(20 \mathrm{~h} \mathrm{~d}^{-1}\right)$ and $21.6 \mathrm{~mol} \mathrm{~m}^{-2} \mathrm{~d}^{-1}\left(24 \mathrm{~h} \mathrm{~d}^{-1}\right)$. Each value is the mean of three experiments, each with 18 replicate plants. Vertical bars represent SE. Different letters indicate statistically significant differences compared by Tukey's HSD test, at $5 \%$ significance level. $P$ values represent the significance of the linear component.
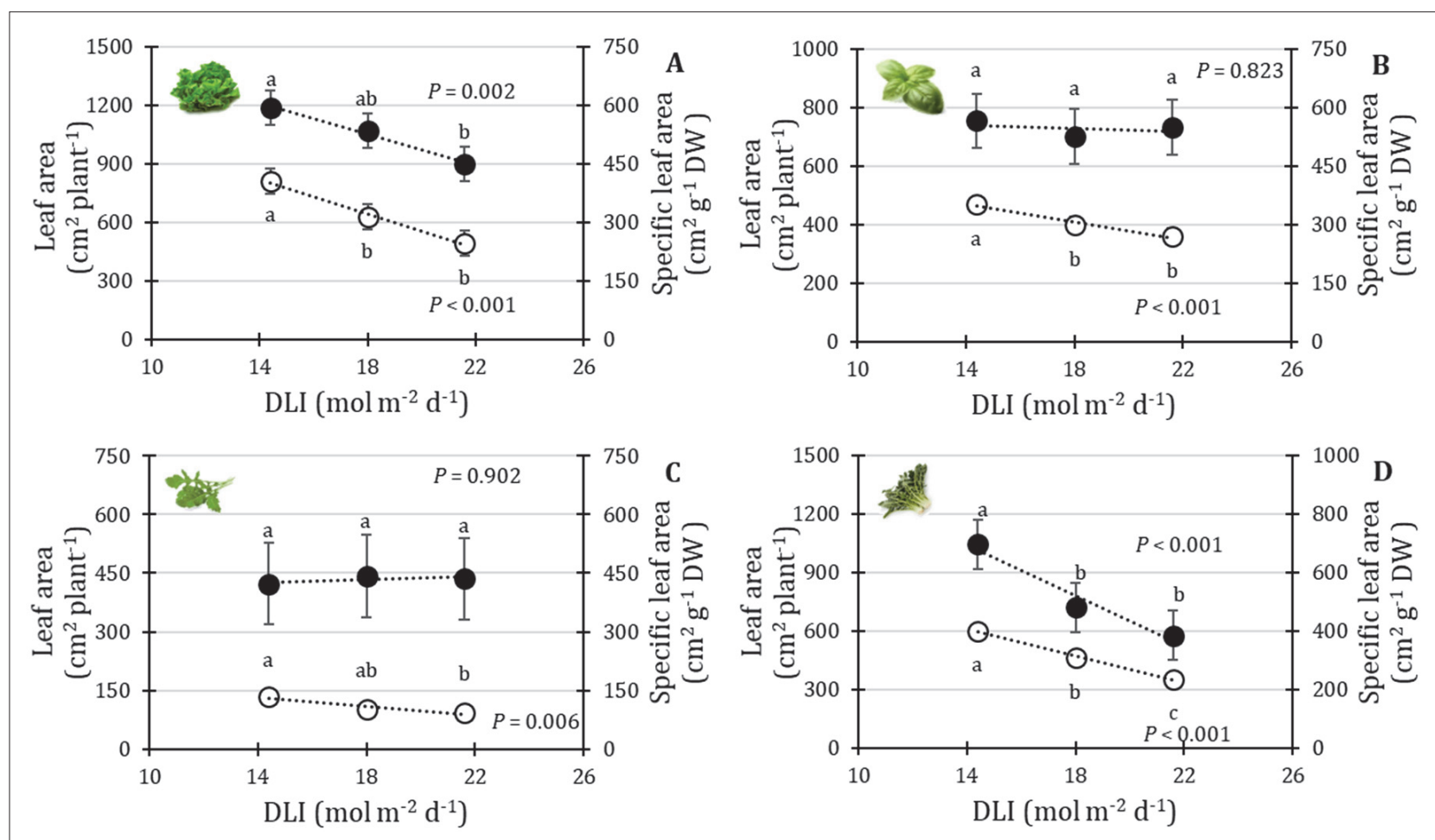

FIGURE 3. Leaf area (closed symbols) and specific leaf area (open symbols) of (A) lettuce, (B) basil, (C) rocket and (D) chicory plants grown under different DLI obtained by changing photoperiod, respectively at $14.4\left(16 \mathrm{~h} \mathrm{~d}^{-1}\right), 18\left(20 \mathrm{~h} \mathrm{~d}^{-1}\right)$ and $21.6 \mathrm{~mol}$ $\mathrm{m}^{-2} \mathrm{~d}^{-1}\left(24 \mathrm{~h} \mathrm{~d}^{-1}\right)$. Each value is the mean of three experiments, each with 18 replicate plants. Vertical bars represent SE. Different letters indicate statistically significant differences compared by Tukey's HSD test, at $5 \%$ significance level. $P$ values represent the significance of the linear component. 


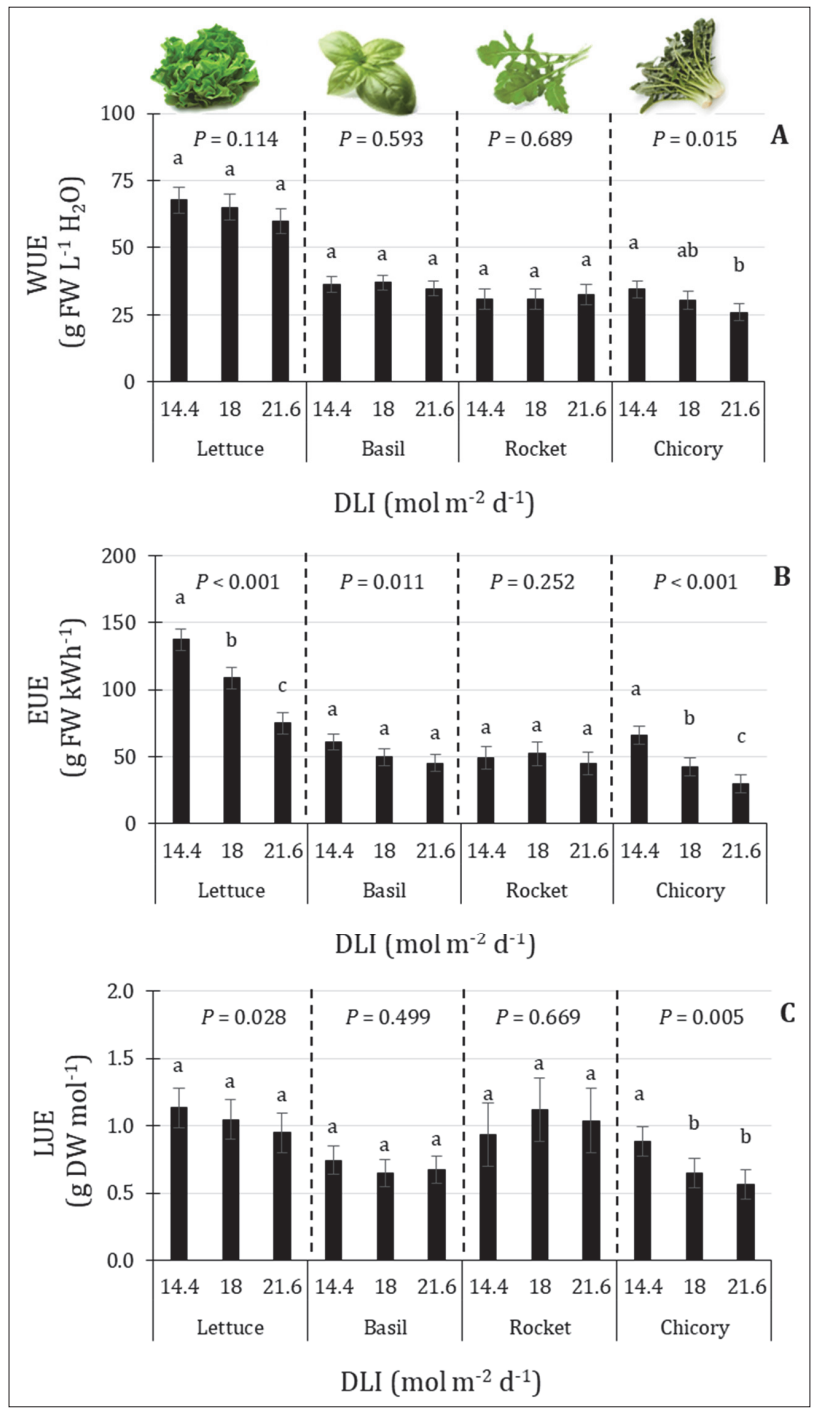

FigURE 4. (A) Water use efficiency, (B) energy use efficiency, and (C) light use efficiency of lettuce, basil, rocket and chicory plants grown under different DLI obtained by changing photoperiod, respectively at $14.4\left(16 \mathrm{~h} \mathrm{~d}^{-1}\right), 18\left(20 \mathrm{~h} \mathrm{~d}^{-1}\right)$ and $21.6 \mathrm{~mol} \mathrm{~m}^{-2} \mathrm{~d}^{-1}\left(24 \mathrm{~h} \mathrm{~d}^{-1}\right)$. Each value is the mean of three experiments, each with 18 replicate plants. Vertical bars represent SE. Different letters indicate statistically significant differences compared by Tukey's HSD test, at $5 \%$ significance level. $P$ values represent the significance of the linear component.

under LED light were, to date, targeted in few researches, mainly focussing on lettuce (Park et al., 2012; Zhang et al., 2018; Viršilè et al., 2019; Yan et al., 2019).

Previous studies on photoperiod management have shown that plant species differently react to $24 \mathrm{~h} \mathrm{~d}^{-1}$ photoperiod (Velez-Ramirez et al., 2011). In several crops, including eggplant (Murage and Masuda, 1997), tomato (Demers et al., 1998), and onion (Van Gestel et al., 2005), continuous light led to leaf necrosis and chlorosis and reduced photosynthetic performances. On the other hand, continuous light was shown to increase biomass production in Arabidopsis (Lepistö et al., 2009) and lettuce (Gaudreau et al., 1994). In the present research, crop-specific responses to changes in DLI were observed. Accordingly, fresh biomass production and leaf area in lettuce (Figures $1 \mathrm{~A}$ and $3 \mathrm{~A}$ ) and chicory (Figures 1D and 3D) were higher in plants grown under $14.4 \mathrm{~mol}$ $\mathrm{m}^{-2} \mathrm{~d}^{-1}$ (photoperiod of $16 \mathrm{~h} \mathrm{~d}^{-1}$ ) as compared to $21.6 \mathrm{~mol}$ $\mathrm{m}^{-2} \mathrm{~d}^{-1}$ (photoperiod of $24 \mathrm{~h} \mathrm{~d}^{-1}$ ). Contrarily, in basil and rocket no statistically significant changes occurred in fresh biomass (Figure 1B, C) and leaf area (Figure 3B, C), even if in rocket a $37 \%$ increase in fresh biomass production of plants grown under the highest DLI as compared to plants grown under the lowest was observed (Figure 1C). Fresh weight of green and red lettuce was previously shown not to vary in response to DLI ranging 13 to $26 \mathrm{~mol} \mathrm{~m}^{-2} \mathrm{~d}^{-1}$ (obtained with photoperiod variations from 12 to $24 \mathrm{~h} \mathrm{~d}^{-1}$, and under constant light intensity of $300 \mu \mathrm{mol} \mathrm{m}{ }^{-2} \mathrm{~s}^{-1}$ supplied by red, blue and far red diodes) (Viršile et al., 2019). However, the same study identified optimal DLI for leaf area development at, respectively, 17 and $19.5 \mathrm{~mol} \mathrm{~m}^{-2} \mathrm{~d}^{-1}$ in green and red lettuce plants (Viršilè et al., 2019). Fresh weight and leaf area of lettuce were also increased when DLI rose from 4.3 to $8.6 \mathrm{~mol} \mathrm{~m}^{-2} \mathrm{~d}^{-1}$ (obtained by varying photoperiod from 12 to $24 \mathrm{~h} \mathrm{~d}^{-1}$ with a light intensity of $100 \mu \mathrm{mol} \mathrm{m}{ }^{-2} \mathrm{~s}^{-1}$ ) in plants cultivated under fluorescent or a white LED lighting system (Park et al., 2012). In Yan et al. (2019), the factorial combination of light intensity and photoperiod was studied by targeting DLI ranging from 10.1 (with $200 \mu \mathrm{mol} \mathrm{m}{ }^{-2} \mathrm{~s}^{-1}$ and $14 \mathrm{~h} \mathrm{~d}^{-1}$ ), to 11.5 (with $200 \mu \mathrm{mol}$ $\mathrm{m}^{-2} \mathrm{~s}^{-1}$ and $16 \mathrm{~h} \mathrm{~d}^{-1}$ ), 12.6 (with $250 \mu \mathrm{mol} \mathrm{m}^{-2} \mathrm{~s}^{-1}$ and $14 \mathrm{~h} \mathrm{~d}^{-1}$ ), and 14.4 (with $250 \mu \mathrm{mol} \mathrm{m}^{-2} \mathrm{~s}^{-1}$ and $16 \mathrm{~h} \mathrm{~d}^{-1}$ ) mol m $\mathrm{m}^{-2} \mathrm{~d}^{-1}$. Under these conditions, the authors suggested that a DLI of 11.5 would promote fresh biomass production in lettuce plants grown under fluorescent or LED lighting systems featuring a RB ratio of 1.1 or 2.1. Furthermore, lettuce biomass production was altered by variations of DLI (obtained by changes in photoperiod from 12 to $16 \mathrm{~h} \mathrm{~d}^{-1}$ ) with significant interactions with other light parameters (spectrum and light intensity) (Zhang et al., 2018). When lettuce plants were grown under fluorescent lamps, a longer photoperiod (ranging 12 to $16 \mathrm{~h} \mathrm{~d}^{-1}$ ) led to higher biomass production independently of the light intensity. Contrarily, in plants grown under LED lights featuring a RB ratio of 1.2 , a photoperiod of $16 \mathrm{~h} \mathrm{~d}^{-1}$ resulted in a greater biomass production with $P P F D \geq 250$ $\mu \mathrm{mol} \mathrm{m}{ }^{-2} \mathrm{~s}^{-1}$ compared to a PPFD $\leq 200 \mu \mathrm{mol} \mathrm{m}^{-2} \mathrm{~s}^{-1}$ (Zhang et al., 2018). A great variability emerges among the observed results of different studies, which may be attributed to the elevated variability in terms of light quality compared (e.g., fluorescent lamps or white LED system in Park et al. [2012], and red blue and far red LEDs system in Viršilè et al. [2019]) or range of DLI tested (e.g., ranging 4.3 to $8.6 \mathrm{~mol} \mathrm{~m}^{-2} \mathrm{~d}^{-1}$ in Park et al. [2012], or 13 to $26 \mathrm{~mol} \mathrm{~m}^{-2} \mathrm{~d}^{-1}$ in Viršilè et al. [2019]). Furthermore, also environmental factors (e.g., temperature and $\mathrm{CO}_{2}$ concentration) may play a fundamental role in plant responses to changes of light parameters, resulting in combined and synergistic effects (Pennisi et al., 2020). Within our former research (Pennisi et al., 2020), where lettuce and basil plants where grown in the same environmental condition as compared to the hereby reported experiments, under red and blue LEDs lighting systems supplying DLIs ranging 5.8 to $17.3 \mathrm{~mol} \mathrm{~m}^{-2} \mathrm{~d}^{-1}$ (obtained by varying PPFD from 100 to $300 \mu \mathrm{mol} \mathrm{m}^{-2} \mathrm{~s}^{-1}$ ), a DLI of $14.4 \mathrm{~mol} \mathrm{~m}^{-2} \mathrm{~d}^{-1}$ improved plants fresh weight, while a further increase of DLI (up to $17.3 \mathrm{~mol}$ $\mathrm{m}^{-2} \mathrm{~d}^{-1}$ ) reduced (in lettuce) or did not change (in basil) the fresh biomass production. Merging these results with the results hereby presented, possibly, an optimum function may be demonstrated, with a DLI of $14.4 \mathrm{~mol} \mathrm{~m}^{-2} \mathrm{~d}^{-1}$ resulting to be the optimal solution for lettuce and basil fresh biomass production.

In the present research, a linear increase in dry weight in response to rising DLI was observed in lettuce and rocket (Figure 1A, C). Similar response to DLI - although at lower DLI values, e.g., 4.3 to $8.6 \mathrm{~mol} \mathrm{~m}^{-2} \mathrm{~d}^{-1}$ - was previously ob- 
served in lettuce (Park et al., 2012). In Yan et al. (2019), optimal DLI for increased lettuce dry weight was defined to be $11.5 \mathrm{~mol} \mathrm{~m}^{-2} \mathrm{~d}^{-1}$. Contrarily, Viršilè et al. (2019) did not observe variations in lettuce dry weight in response to changes in DLI between 13 and $26 \mathrm{~mol} \mathrm{~m}^{-2} \mathrm{~d}^{-1}$. Greater dry biomass production due to a prolonged photoperiod was previously associated with increase of leaf chlorophyll content in geranium, impatiens, pansy and petunia (Langton et al., 2003), and in both lettuce and tsukena (Fukuda et al., 2002). Similarly, in the present research, chlorophyll content linearly increased in response to DLI in basil, rocket and chicory (Table 1).

The rise of dry weight in lettuce plants (Figure 1A) in response to higher DLI resulted in increased dry matter content (Figure 2A), as also observed in basil (Figure 2B) and chicory (Figure 2D). The increase in dry matter content in plants undergoing longer days was previously related with higher carbohydrate production through photosynthesis (Zhang et al., 2018), and considered a qualitative marker (Scuderi et al., 2011). This hypothesis is further substantiated by the observed trends for SLA, which in all the studied crops presented a linear negative response to increase of DLI (Figure 3). SLA decreases in response to higher DLI are, however, mainly to be associated with decrease in leaf area in chicory, increase of dry weight in rocket and the combination of both trends in lettuce. These trends confirm the formerly reported difficulties in finding univocal interpretations of plant response to photoperiodic variations (Adams and Langton, 2005) across different plant species. The increase in dry weight (Figure 1A) and dry matter (Figure 2A) in lettuce plants exposed to long photoperiods is consistent with the hypothesis that longer days resulted in increased net assimilation ratio (NAR, e.g., the plant growth rate per unit of leaf area, closely related to the leaf photosynthetic rate minus respiration), rather than increased leaf area ratio (LAR, e.g., the ratio between plant leaf area and total plant biomass), as evident from the observed decrease in both leaf area and SLA (Figure 3A). While there is not a universal agreement on the mechanisms involved in photoperiodic responses, gains in dry biomass accumulation have been generally associated with either leaf area, chlorophyll content or photosynthetic efficiency (Langton et al., 2003; Adams and Langton, 2005). Accordingly, despite the fact that longer days never resulted in increased leaf area (Figure 3), they significantly reduced stomatal conductance in lettuce and basil while fostering increased chlorophyll content in basil and chicory (Table 1), ultimately resulting in increased dry matter content at highest DLI in lettuce (Figure 2A), basil (Figure 2B) and chicory (Figure 2D).

Alteration of plant circadian rhythm due to longer photoperiod was previously suggested to affect stomatal functionality (Arve et al., 2013), through modifications of endogenous hormone (e.g., abscisic acid) levels in plant tissues (Tallman, 2004). In the present research, increase in DLI created by prolonging the photoperiod resulted in linear decreases of stomatal conductance in both lettuce and basil (Table 1). The induction of stomatal closure by long photoperiod was previously observed in peanuts (Arachis hypogea) (Rowell et al., 1999), and associated with decrease of photosynthetic rates with modification of the Rubisco enzyme from oxygenation to carboxylation in plants grown under continuous light. The downregulation of photosynthesis in plants under continuous light was also claimed to be caused by saturation of starch and sugar concentrations in plant tissues (Van Gestel et al., 2005), overall also leading to reduced stomatal opening (Velez-Ramirez et al., 2011).

\section{A DLI of $14.4 \mathrm{~mol} \mathrm{~m}^{-2} \mathrm{~d}^{-1}$ (16 $\mathrm{h} \mathrm{d}^{-1}$ photoperiod) enhances energy and light use efficiency in indoor cultivation of leafy vegetables and herbs}

Indoor plant cultivation with artificial lighting is claimed to allow for massive water saving thanks to the use of closedloop hydroponics, the recovery of the water transpired by plants and the possibility to adjust environmental conditions to the plant needs, with WUE values up to 50-times higher as compared to traditional cultivation systems (e.g., open field or greenhouse) (Kozai, 2013). Accordingly, observed WUE values reached up to 68 (lettuce), 37 (basil), 32 (rocket) and $34 \mathrm{~g} \mathrm{FW} \mathrm{L}^{-1} \mathrm{H}_{2} \mathrm{O}$ (chicory) (Figure 4A), resulting in increases up to 20 -folds as compared to traditional cultivation systems (Orsini et al., 2020).

To date, stomatal behaviour and photosynthetic functionality were reported to vary in response to changes in DLI (Arve et al., 2013). When DLI was increased from 5.8 to 17.3 mol m $\mathrm{m}^{-2} \mathrm{~d}^{-1}$ by means of growing light intensity (PPFD ranging 100 to $300 \mu \mathrm{mol} \mathrm{m} \mathrm{m}^{-2} \mathrm{~s}^{-1}$ ), WUE in lettuce resulted to grow up to a DLI of $11.5 \mathrm{~mol} \mathrm{~m}^{-2} \mathrm{~d}^{-1}$, while no further variations occurred when higher DLI values were supplied (Pennisi et al., 2020). In the same study, WUE in basil was shown to increase from 5.8 to $14.4 \mathrm{~mol} \mathrm{~m}^{-2} \mathrm{~d}^{-1}$, while it did not vary between 14.4 and $17.3 \mathrm{~mol} \mathrm{~m}^{-2} \mathrm{~d}^{-1}$ (Pennisi et al., 2020). In the present research, WUE was not affected by changes in DLI in lettuce, basil and rocket, whereas in chicory plants, it was higher at the lowest DLI (Figure 4A). It may be advanced that when DLI increases, a decrease in photosystem efficiency in chicory occurred (Van Gestel et al., 2005), which overall resulted in reduced plant fresh biomass (Figure 1D) and therefore in WUE decrease (Figure 4A).

Energetic requirements are the most important factors limiting the expansion of indoor cultivation worldwide (Kozai, 2016b). In the present research, varying DLI altered both the electricity needs and the crop fresh biomass production in lettuce and chicory (Figure 1A, D), resulting in highest EUE values when plants were grown under $14.4 \mathrm{~mol}$ $\mathrm{m}^{-2} \mathrm{~d}^{-1}$ (Figure 4B). Interestingly, an optimum function in EUE response to DLI changes (obtained through modifications in light intensity) was also recently reported for both lettuce and basil crops, where highest EUE values were observed at $14.4 \mathrm{~mol} \mathrm{~m}^{-2} \mathrm{~d}^{-1}$, as compared with higher DLI (Pennisi et al., 2020). To further comprehend how DLI affected EUE in the studied crops, a comparison against previous researches (Pennisi et al., 2019a, b, c) under similar experimental conditions (RB=3, DLI of $12.4 \mathrm{~mol} \mathrm{~m}^{-2} \mathrm{~d}^{-1}$ obtained by applying $215 \mu \mathrm{mol} \mathrm{m}^{-2} \mathrm{~s}^{-1}$ for $16 \mathrm{~h} \mathrm{~d}^{-1}$ ) is hereby proposed. Accordingly, while the current research yielded EUE in lettuce up to $138 \mathrm{~g} \mathrm{FW} \mathrm{kWh}^{-1}$ (Figure 4B), in the previous experience it was limited to $91 \mathrm{~g} \mathrm{FW} \mathrm{kWh}^{-1}$ (Pennisi et al., 2019b). Similarly, EUE in basil plants was hereby found to reach $61 \mathrm{~g}$ FW $\mathrm{kWh}^{-1}$ (Figure 4B), against previous reports of $33 \mathrm{~g} \mathrm{FW}$ $\mathrm{kWh}^{-1}$ (Pennisi et al., 2019a). Finally, while EUE in chicory and rocket reached 65 and $50 \mathrm{~g} \mathrm{FW} \mathrm{kWh}^{-1}$ (Figure 4B), previous experiences reported values of 19 and $25 \mathrm{~g} \mathrm{FW} \mathrm{kWh}^{-1}$ for these two crops, respectively (Pennisi et al., 2019c). The substantial increases in EUE brought by the current study are to be mainly associated with changes in intrinsic characteristics of the light source, and specifically the lamp energy consumption $\left(\mathrm{W} \mathrm{m}^{-2}\right)$ and, consequently, its Photosynthetic Photon Efficacy (PPE, expressed as $\mu \mathrm{mol} \mathrm{J}^{-1}$ ) (Kusuma et al., 2020). Accordingly, the higher EUE should be associated with a decrease in lamp energy consumption (164 vs. $219 \mathrm{~W} \mathrm{~m}^{-2}$ ) and a concurrent increase in PPE (1.52 vs. 0.98 $\mu \mathrm{mol} \mathrm{\textrm {J } ^ { - 1 }}$ ) in the lamps used for the current research as com- 
pared with those adopted in the previous experiments (Pennisi et al., 2019a, b, c). Indeed, lamps in all these experiments were supplied by the same manufacturer, and changes in the lamp performances over time shall mainly be associated with the rapid technological evolution that the sector is facing (Kusuma et al., 2020). Accordingly, LUE may turn out as a more stable indicator as compared with EUE on the plant response to different DLI. Significant response of LUE to DLI increase was detected in lettuce and chicory, where a linear negative trend was observed (Figure 4C). The absence of effects on LUE to changes in DLI in rocket (Figure 4C) should be related to a positive effect on dry biomass, which indeed resulted increased $(+66 \%)$ in plants grown under the highest DLI as compared to those grown under the lowest (Figure 1C). Light spectral composition and the overall growing environment may also affect plant LUE (Ibaraki, 2016; Cocetta et al., 2017). Nevertheless, the hereby obtained LUE value for lettuce are also impressive when compared with LUE values (0.37 $\mathrm{g} \mathrm{DW} \mathrm{mol}^{-1}$ ) estimated by Graamans et al. (2018), in a study where a greenhouse lettuce growth model (Van Henten, 1994) was adapted to indoor farming conditions. Similarly, previous indication of low LUE (ranging 0.15 to $0.18 \mathrm{~g}$ DW mol$^{-1}$ ) in a growth chamber supplied with HPS lamps may have been affected by the wider spectrum of the light source (El-Nakhel et al., 2019). On the other hand, when similar light spectral features and environmental conditions were used (Pennisi et al., 2020), LUE values reached similar figures (e.g., up to 1.08 and $0.70 \mathrm{~g} \mathrm{DW} \mathrm{mol}^{-1}$, in lettuce and basil, respectively).

\section{Conclusions}

The hereby presented study highlighted species-specific changes in plant morphology and physiological response to DLI as varied by photoperiod. The adoption of a DLI of $14.4 \mathrm{~mol} \mathrm{~m}^{-2} \mathrm{~d}^{-1}$ (16 $\mathrm{h} \mathrm{d}^{-1}$ photoperiod) enabled to obtain a greater fresh biomass production and leaf area in lettuce and chicory plants as compared to plants grown under a DLI of $21.6 \mathrm{~mol} \mathrm{~m}^{-2} \mathrm{~d}^{-1}$ (24 $\mathrm{h} \mathrm{d}^{-1}$ photoperiod). Furthermore, dry matter content in lettuce, basil and chicory was enhanced by the increase of DLI. Looking at the capacity to transform resources, energy use efficiency (EUE), expressed in grams of fresh biomass produced per unit of energy (in lettuce, basil and chicory plants), and light use efficiency (LUE), expressed in grams of dry biomass per light integral (in lettuce and chicory plants), linearly decreased with the increase of DLI, while EUE remained constant in rocket and LUE in basil and rocket. Furthermore, WUE of chicory plants resulted greater under a DLI of $14.4 \mathrm{~mol} \mathrm{~m}^{-2} \mathrm{~d}^{-1}$ as compared to $21.6 \mathrm{~mol}$ $\mathrm{m}^{-2} \mathrm{~d}^{-1}$. From the study it may be concluded that indoor cultivation (using $\mathrm{RB}=3 \mathrm{LED}$ lamps providing $\mathrm{PPFD}=250 \mu \mathrm{mol}$ $\mathrm{m}^{-2} \mathrm{~s}^{-1}$ ) of lettuce and chicory may be improved supplying a photoperiod of $16 \mathrm{~h} \mathrm{~d}^{-1}$ resulting in a DLI of $14.4 \mathrm{~mol} \mathrm{~m}^{-2} \mathrm{~d}^{-1}$.

\section{Acknowledgments}

The research leading to this publication has received funding from the European Union's Horizon 2020 research and innovation programme under grant agreement No. 862663. The publication reflects the authors' views. The Research Executive Agency (REA) is not liable for any use that may be made of the information contained therein.

\section{References}

Adams, S.R., and Langton, F.A. (2005). Photoperiod and plant growth: a review. J. Hortic. Sci. Biotechnol. 80(1), 2-10. https://doi.org/10.1 080/14620316.2005.11511882.
Al-Chalabi, M. (2015). Vertical farming: Skyscraper sustainability? Sust. Cities Soc. 18, 74-77. https://doi.org/10.1016/j. scs.2015.06.003.

Arve, L.E., Terfa, M.T., Gislerød, H.R., Olsen, J.E., and Torre, S. (2013). High relative air humidity and continuous light reduce stomata functionality by affecting the ABA regulation in rose leaves. Plant, Cell Environm. 36(2), 382-392. https://doi.org/10.1111/j.13653040.2012.02580.x.

Banerjee, C., and Adenaeuer, L. (2014). Up, up and away! The economics of vertical farming. J. Agr. Stud. 2, 40-60. https://doi. org/10.5296/jas.v2i1.4526.

Baumbauer, D.A., Schmidt, C.B., and Burgess, M.H. (2019). Leaf lettuce yield is more sensitive to low daily light integral than kale and spinach. HortScience 54(12), 2159-2162. https://doi. org/10.21273/HORTSCI14288-19.

Beaman, A.R., Gladon, R.J., and Schrader, J.A. (2009). Sweet basil requires an irradiance of $500 \mu \mathrm{mol} \mathrm{m}^{-2} \mathrm{~s}^{-1}$ for greatest edible biomass production. HortScience 44, 64-67. https://doi.org/10.21273/ HORTSCI.44.1.64.

Carvalho, S.D., Schwieterman, M.L., Abrahan, C.E., Colquhoun, T.A., and Folta, K.M. (2016). Light quality dependent changes in morphology, antioxidant capacity, and volatile production in sweet basil (Ocimum basilicum). Front. Plant Sci. 7, 1328. https://doi. org/10.3389/fpls.2016.0132.

Clavijo-Herrera, J., Van Santen, E., and Gómez, C. (2018). Growth, water-use efficiency, stomatal conductance, and nitrogen uptake of two lettuce cultivars grown under different percentages of blue and red light. Horticulturae 4, 16. https://doi.org/10.3390/ horticulturae 4030016

Cocetta, G., Casciani, D., Bulgari, R., Musante, F., Kołton, A., Rossi, M., and Ferrante, A. (2017). Light use efficiency for vegetables production in protected and indoor environments. Eur. Phys. J. Plus 132(1), 1-15. https://doi.org/10.1140/epjp/i2017-11298-x.

Craig, D.S., and Runkle, E.S. (2013). A moderate to high red to farred light ratio from light-emitting diodes controls flowering of short-day plants. J. Am. Soc. Hortic. Sci. 138, 167-172. https://doi. org/10.21273/JASHS.138.3.167.

Demers, D.A., Dorais, M., Wien, C.H., and Gosselin, A. (1998). Effects of supplemental light duration on greenhouse tomato (Lycopersicon esculentum Mill.) plants and fruit yields. Sci. Hortic. 74, 295-306. https://doi.org/10.1016/S0304-4238(98)00097-1.

Dou, H., Niu, G., Gu, M., and Masabni, J.G. (2018). Responses of sweet basil to different daily light integrals in photosynthesis, morphology, yield, and nutritional quality. HortScience 53, 496-503. https://doi. org/10.21273/HORTSCI12785-17.

Dougher, T., and Bugbee, B. (2001). Differences in the response of wheat, soybean and lettuce to reduced blue radiation. Photochem. Photobiol. 73, 199-207. https://doi.org/10.1562/00318655(2001)0730199DITROW2.0.CO2.

El-Nakhel, C., Pannico, A., Kyriacou, M.C., Giordano, M., De Pascale, S., and Rouphael, Y. (2019). Macronutrient deprivation eustress elicits differential secondary metabolites in red and green-pigmented butterhead lettuce grown in closed soilless system. J. Sci. Food Agric. 99(15), 6962-6972. https://doi.org/10.1002/jsfa.9985.

Fukuda, N., Nishimura, S., and Fumiki, Y. (2002). Effect of supplemental lighting during the period from middle of night to morning on photosynthesis and leaf thickness of lettuce (Lactuca sativa L.) and tsukena (Brassica campestris L.). Acta Hortic. 633, 237-244. https://doi.org/10.17660/ActaHortic.2004.633.28.

Gaudreau, L., Charbonneau, J., Vézina, L.P., and Gosselin, A. (1994). Photoperiod and photosynthetic photon flux influence growth and quality of greenhouse-grown lettuce. HortScience 29, 1285-1289. https://doi.org/10.21273/HORTSCI.29.11.1285. 
Goins, G.D., Yorio, N.C., Sanwo, M.M., and Brown, C.S. (1997). Photomorphogenesis, photosynthesis, and seed yield of wheat plants grown under red light-emitting diodes (LEDs) with and without supplemental blue lighting. J. Exp. Bot. 48, 1407-1413. https://doi. org/10.1093/jxb/48.7.1407.

Gómez, C., and Izzo, L.G. (2018). Increasing efficiency of crop production with LEDs. AIMS Agr. Food 3, 135-153. https://doi. org/10.3934/agrfood.2018.2.135.

Graamans, L., Baeza, E., Van Den Dobbelsteen, A., Tsafaras, I., and Stanghellini, C. (2018). Plant factories versus greenhouses: comparison of resource use efficiency. Agric. Sys. 160, 31-43. https://doi.org/10.1016/j.agsy.2017.11.003.

Greenham, K., and McClung, C. (2015). Integrating circadian dynamics with physiological processes in plants. Nat. Rev. Genet. 16, 598-610. https://doi.org/10.1038/nrg3976.

Ibaraki, Y. (2016). Lighting efficiency in plant production under artificial lighting and plant growth modeling for evaluating the lighting efficiency. In LED Lighting for Urban Agriculture, T. Kozai, K. Fujiwara, and E.S. Runkle, eds. (Singapore: Springer), p. 151-161. https://doi.org/10.1007/978-981-10-1848-0_11.

Ikeda, A., Nakayama, S., Kitaya, Y., and Yabuki, K. (1987). Effects of photoperiod, $\mathrm{CO}_{2}$ concentration, and light intensity on growth and net photosynthetic rates of lettuce and turnip. Acta Hortic. 229, 273282. https://doi.org/10.17660/ActaHortic.1988.229.29.

Jackson, S.D. (2009). Plant responses to photoperiod. New Phytol. 181, 517-531. https://doi.org/10.1111/j.1469-8137.2008.02681.x.

Kang, J.H., KrishnaKumar, S., Atulba, S.L.S., Jeong, B.R., and Hwang, S.J. (2013). Light intensity and photoperiod influence the growth and development of hydroponically grown leaf lettuce in a closed-type plant factory system. Hortic. Environm. Biotechnol. 54, 501-509. https://doi.org/10.1007/s13580-013-0109-8.

Kozai, T. (2013). Resource use efficiency of closed plant production system with artificial light: Concept, estimation and application to plant factory. Proc. Jpn. Acad. B 89, 447-461, https://doi. org/10.2183/pjab.89.447.

Kozai, T. (2016a). Why LED lighting for urban agriculture? In LED Lighting for Urban Agriculture, T. Kozai, K. Fujiwara, and E.S. Runkle, eds. (Singapore: Springer), p. 3-18. https://doi.org/10.1007/978981-10-1848-0_1.

Kozai, T. (2016b). PFAL business and R\&D in the world: Current status and perspectives. In Plant Factory: An Indoor Vertical Farming System for Efficient Quality Food Production, T. Kozai, G. Niu, and M. Takagaki, eds. (Amsterdam: Academic Press), p. 35-68.

Kozai, T. (2020). Plant production process, floor plan, and layout of PFAL. In Plant Factory: An Indoor Vertical Farming System for Efficient Quality Food Production, T. Kozai, G. Niu, and M. Takagaki, eds. (Amsterdam: Academic Press), p. 261-271. https://doi. org/10.1016/B978-0-12-816691-8.00019-4

Kozai, T., and Niu, G. (2020). Plant factory as a resource-efficient closed plant production system. In Plant Factory: An Indoor Vertical Farming System for Efficient Quality Food Production, T. Kozai, G. Niu, and M. Takagaki, eds. (Amsterdam: Academic Press), p. 93115. https://doi.org/10.1016/B978-0-12-816691-8.00005-4.

Kusuma, P., Pattison, P.M., and Bugbee, B. (2020). From physics to fixtures to food: current and potential LED efficacy. Hortic. Res. 7(1), 1-9. https://doi.org/10.1038/s41438-020-0283-7.

Langton, F.A., Adams, S.R., and Cockshull, K.E. (2003). Effects of photoperiod on leaf greenness of four bedding plant species. J. Hortic. Sci. Biotechnol. 78(3), 400-404. https://doi.org/10.1080/ 14620316.2003.11511638.

Lee, H.I., and Kim, Y.H. (2013). Utilization efficiencies of electric energy and photosynthetically active radiation of lettuce grown under red LED, blue LED and fluorescent lamps with different photoperiods. J. Biosys. Eng. 38, 279-286. https://doi.org/10.5307/ JBE.2013.38.4.279.

Lefsrud, M.G., Kopsell, D.A., Augé, R.M., and Both, A.J. (2006). Biomass production and pigment accumulation in kale grown under increasing photoperiods. HortScience 41(3), 603-606. https://doi. org/10.21273/HORTSCI.41.3.603.

Lepistö, A., Kangasjärvi, S., Luomala, E.M., Brader, G., Sipari, N., Keränen, M., Keinänen, M., and Rintamäki, E. (2009). Chloroplast NADPH-thioredoxin reductase interacts with photoperiodic development in Arabidopsis. Plant Physiol. 149, 1261-1276. https:// doi.org/10.1104/pp.108.133777.

Massa, G.D., Kim, H.H., Wheeler, R.M., and Mitchell, C.A. (2008). Plant productivity in response to LED lighting. HortScience 43, 19511956. https://doi.org/10.21273/HORTSCI.43.7.1951.

Meng, Q., and Runkle, E.S. (2019). Far-red radiation interacts with relative and absolute blue and red photon flux densities to regulate growth, morphology, and pigmentation of lettuce and basil seedlings. Sci. Hortic. 255, 269-280. https://doi.org/10.1016/j. scienta.2019.05.030.

Morrow, R.C. (2008). LED lighting in horticulture. HortScience 43, 1947-1950. https://doi.org/10.21273/HORTSCI.43.7.1947.

Murage, E.N., and Masuda, M. (1997). Response of pepper and eggplant to continuous light in relation to leaf chlorosis and activities of antioxidative enzymes. Sci. Hortic. 70, 269-279. https:// doi.org/10.1016/S0304-4238(97)00078-2.

Nájera, C., and Urrestarazu, M. (2019). Effect of the intensity and spectral quality of LED light on yield and nitrate accumulation in vegetables. HortScience 54(10), 1745-1750. https://doi. org/10.21273/HORTSCI14263-19.

Olle, M., and Viršile, A. (2013). The effects of light-emitting diode lighting on greenhouse plant growth and quality. Agric. Food Sci. 22, 223-234. https://doi.org/10.23986/afsci.7897.

Orsini, F., Pennisi, G., Zulfiqar, F., and Gianquinto, G. (2020). Sustainable use of resources in indoor farms with artificial lighting. Eur. J. Hortic. Sci. 85, 297-309. https://doi.org/10.17660/ eJHS.2020/85.5.1.

Park, J.E., Park, Y.G., Jeong, B.R., and Hwang, S.J. (2012). Growth and anthocyanin content of lettuce as affected by artificial light source and photoperiod in a closed-type plant production system. Korean J. Hortic. Sci. Technol. 30, 673-679. https://doi.org/10.7235/hort.2012.12020.

Pennisi, G., Blasioli, S., Cellini, A., Maia, L., Crepaldi, A., Braschi, I., Spinelli, F., Nicola, S., Fernandez, J.A., Stanghellini, C., Marcelis, L.F., Orsini, F., and Gianquinto, G. (2019a). Unravelling the role of Red:Blue LED lights on resource use efficiency and nutritional properties of indoor grown sweet basil. Front. Plant Sci. 10, 305. https://doi.org/10.3389/fpls.2019.00305.

Pennisi, G., Orsini, F., Blasioli, S., Cellini, A., Crepaldi, A., Braschi, I., Spinelli, F., Nicola, S., Fernandez, J.A., Stanghellini, C., Gianquinto, G., and Marcelis, L.F.M. (2019b). Resource use efficiency of indoor lettuce (Lactuca sativa L.) cultivation as affected by red:blue ratio provided by LED lighting. Nature Sci. Rep. 9, 1-11. https://doi. org/10.1038/s41598-019-50783-z.

Pennisi, G., Sanyé-Mengual, E., Orsini, F., Crepaldi, A., Nicola, S., Ochoa, J., Fernandez, J.A., and Gianquinto, G. (2019c). Modelling environmental burdens of indoor-grown vegetables and herbs as affected by red and blue LED lighting. Sustainability 11, 4063. https://doi.org/10.3390/su11154063.

Pennisi, G., Pistillo, A., Orsini, F., Cellini, A., Spinelli, F., Nicola, S., Fernández, J.A., Crepaldi, A., Gianquinto, G., and Marcelis, L.F.M. (2020). Optimal light intensity for sustainable water and energy use in indoor cultivation of lettuce and basil under red and 
blue LEDs. Sci. Hortic. 272, 109508. https://doi.org/10.1016/j. scienta.2020.109508.

Poorter, H., Niinemets, Ü., Ntagkas, N., Siebenkäs, A., Mäenpää, M., Matsubara, S., and Pons, T.L. (2019). A meta-analysis of plant responses to light intensity for 70 traits ranging from molecules to whole plant performance. New Phytol. 223, 1073-1105. https://doi. org/10.1111/nph.15754

Rowell, T., Mortley, D.G., Loretan, P.A., Bonsi, C.K., and Hill, W.A. (1999). Continuous daily light period and temperature influence peanut yield in nutrient film technique. Crop Sci. 39, 1111-1114. https://doi.org/10.2135/cropsci1999.0011183X003900040026x.

Scuderi, D., Restuccia, C., Chisari, M., Barbagallo, R.N., Caggia, C., and Giuffrida, F. (2011). Salinity of nutrient solution influences the shelf-life of fresh-cut lettuce grown in floating system. Postharvest Biol. Technol. 59(2), 132-137. https://doi.org/10.1016/j. postharvbio.2010.08.016.

Shimizu, H., Saito, Y., Nakashima, H., Miyasaka, J., and Ohdoi, K. (2011). Light environment optimization for lettuce growth in plant factory. IFAC Proc. Vol. 44, 605-609. https://doi.org/10.3182/20110828-6IT-1002.02683.

Singh, D., Basu, C., Meinhardt-Wollweber, M., and Roth, B. (2015). LEDs for energy efficient greenhouse lighting. Renew. Sust. Energ. Rev. 49, 139-147. https://doi.org/10.1016/j.rser.2015.04.117.

Tallman, G. (2004). Are diurnal patterns of stomatal movement the result of alternating metabolism of endogenous guard cell ABA and accumulation of ABA delivered to the apoplast around guard cells by transpiration? J. Exp. Bot. 55, 1963-1976. https://doi.org/10.1093/ jxb/erh212.

Taulavuori, K., Pyysalo, A., Taulavuori, E., and Julkunen-Tiitto, R. (2018). Responses of phenolic acid and flavonoid synthesis to blue and blue-violet light depends on plant species. Environ. Exp. Bot. 150, 183-187. https://doi.org/10.1016/j.envexpbot.2018.03.016.

Van Gestel, N.C., Nesbit, A.D., Gordon, E.P., Green, C., Paré, P.W., Thompson, L., Peffley, E.B., and Tissue, D.T. (2005). Continuous light may induce photosynthetic downregulation in onion-consequences for growth and biomass partitioning. Physiol. Plant. 125, 235-246. https://doi.org/0.1111/j.1399-3054.2005.00560.x.

Van Henten, E.J. (1994). Validation of a dynamic lettuce growth model for greenhouse climate control. Agric. Syst. 45(1), 55-72. http://dx.doi.org/10.1016/S0308-521X (94)90280-1.

Velez-Ramirez, A.I., Van Ieperen, W., Vreugdenhil, D., and Millenaar, F.F. (2011). Plants under continuous light. Trends Plant Sci. 16, 310318. https://doi.org/10.1016/j.tplants.2011.02.003.

Viršilè, A., Brazaitytė, A., Vaštakaitė-Kairienė, V., Miliauskienė, J., Jankauskienė, J., Novičkovas, A., and Samuolienė, G. (2019). Lighting intensity and photoperiod serves tailoring nitrate assimilation indices in red and green baby leaf lettuce. J. Sci. Food Agric. 99(14), 6608-6619. https://doi.org/10.1002/jsfa.9948.

Yan, Z., He, D., Niu, G., Zhou, Q., and Qu, Y. (2019). Growth, nutritional quality, and energy use efficiency of hydroponic lettuce as influenced by daily light integrals exposed to white versus white plus red lightemitting diodes. HortScience 54(10), 1737-1744. https://doi. org/10.21273/HORTSCI14236-19.

Yeh, N., and Chung, J.P. (2009). High-brightness LEDs - Energy efficient lighting sources and their potential in indoor plant cultivation. Renew. Sust. Energy Rev. 13, 2175-2180. https://doi. org/10.1016/j.rser.2009.01.027.

Zhang, X., He, D., Niu, G., Yan, Z., and Song, J. (2018). Effects of environment lighting on the growth, photosynthesis, and quality of hydroponic lettuce in a plant factory. Int. J. Agr. Biol. Eng. 11, 33-40. https://doi.org/10.25165/j.ijabe.20181102.3240.
Received: May 18, 2020

Accepted: Sep. 7, 2020

Addresses of authors:

G. Pennisi ${ }^{1}$, F. Orsini ${ }^{1}$, M. Landolfo ${ }^{1}$, A. Pistillo ${ }^{1}$, A. Crepaldi ${ }^{2}$,

S. Nicola ${ }^{3}$, J.A. Fernández ${ }^{4}$ L.F.M. Marcelis ${ }^{5}$ and

G. Gianquinto ${ }^{1}$

${ }^{1}$ DISTAL, Agricultural and Food Sciences Department, Alma

Mater Studiorum - University of Bologna, Bologna, Italy

${ }^{2}$ Flytech s.r.l., Belluno, Italy

${ }^{3}$ DISAFA-VEGMAP, Department of Agricultural, Forest and

Food Sciences, University of Turin, Turin, Italy

${ }^{4}$ Departamento de Ingeniería Agronómica, Universidad

Politécnica de Cartagena, Cartagena, Spain

${ }^{5}$ Wageningen UR Horticulture and Product Physiology, Wageningen, The Netherlands 
International Workshop on Vertical Farming

13-15 October 2019

Wageningen, The Netherlands

Sponsored by
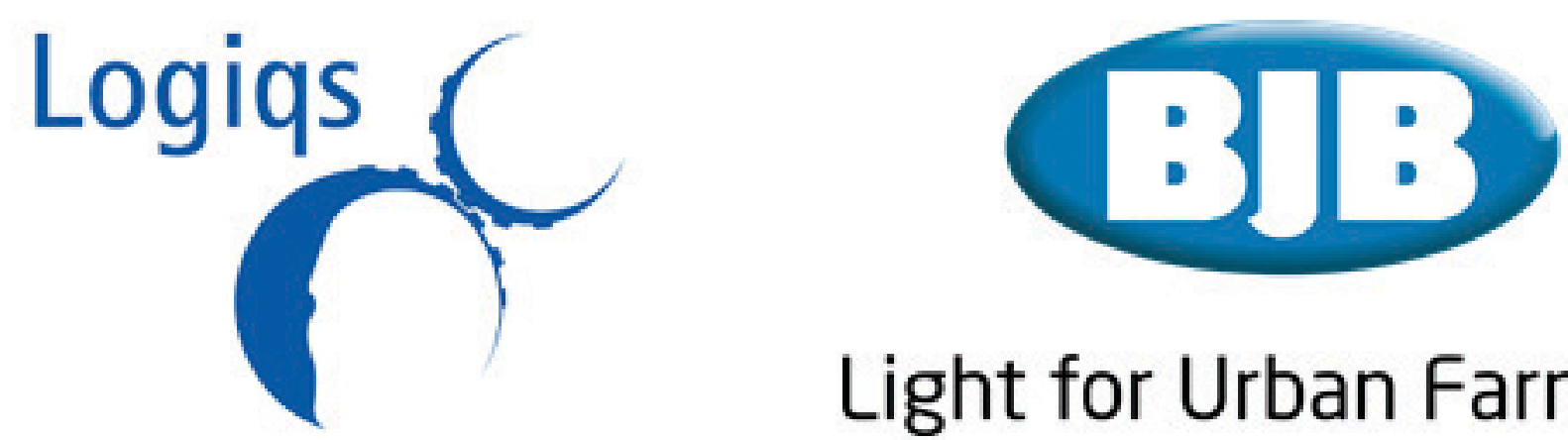

\section{Light for Urban Farming}

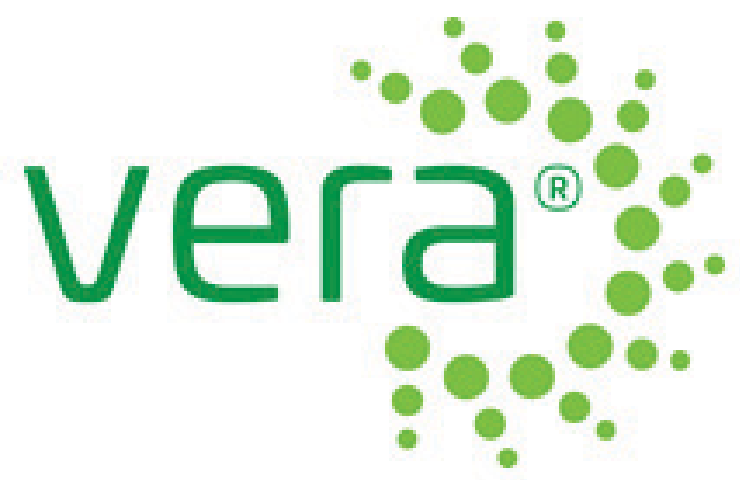

Nouryon

\section{Chelated} Micronutrients
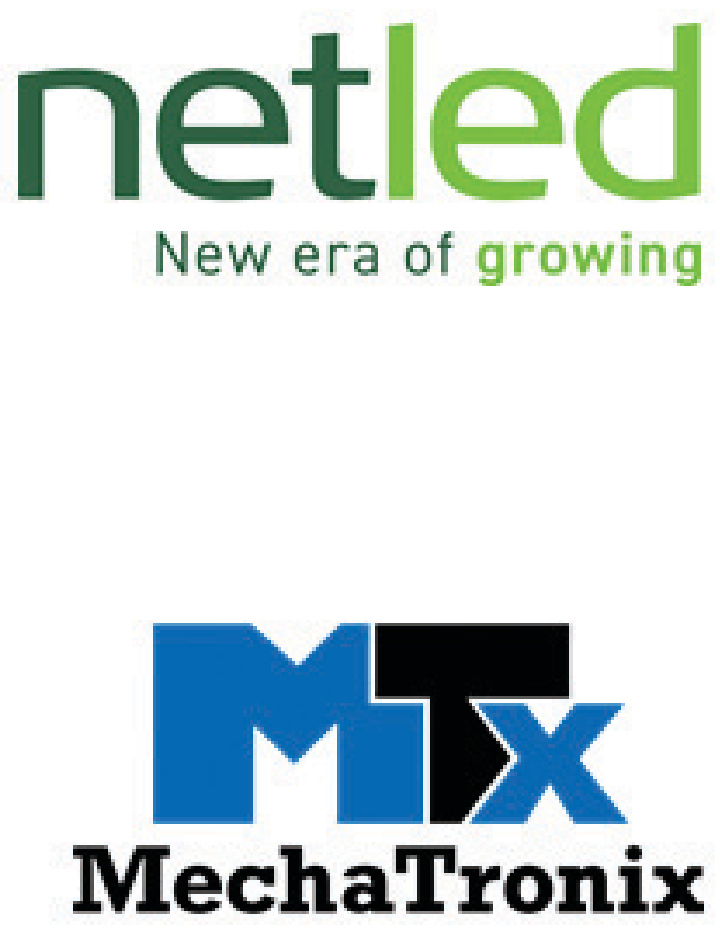

Fடㅁㅁய

$$
\text { F L U E N C E }
$$

